\title{
Methods of Using Programmed Means to Organize Practical Training for Improving the Professional Skills of Future Teachers of Fine Arts
}

\author{
Azimov Sanjar Samadovich \\ Bukhara State University Uzbekistan
}

\begin{abstract}
The combination of theoretical and practical knowledge in the professional training of future teachers of fine arts, the importance of theoretical and practical exercises in the subject of Composition. The theoretical basis for improving the professional training of future teachers of fine arts is systematically analyzed in the article.

The didactic possibilities of further increasing the scientific motivation of students through the use of software means in the educational process were studied.

To form the virtual practical training in the teaching of the subject "Composition" in the direction of education 5110800-Fine Arts and Engineering Graphics in higher education, to develop the methodological recommendations for its use, are pedagogically based.

Methodology for developing a programmed, electronic educational-methodical complex on the subject of "Composition" which covers (introduction, normative documents, lectures, practical classes, self-study topics, presentations, animations, programmed control test, keywords and terms, used literature, information about the authors) is recommended.

Thoughts about the actual tasks of the development of the educational system in increasing the efficiency of the acquisition of the subject "Composition" are stated.

Keywords: Education system, composition, programmed electronic educational-methodical complex, software
\end{abstract}

\section{INTRODUCTION}

Modern information technologies in the education system, great importance is attached to the introduction and use of programmed educational tools, the full satisfaction of citizens' needs for information, access to the global information community and the creation of favorable conditions for access to global information resources.

In pursuance of the objectives of the Decree of the President of the Republic of Uzbekistan No. PD2909 - "On measures for further development of the higher education system" dated April 20, 2017, Decree of the President of the Republic of Uzbekistan No. PD-5099 - "On measures to radically improve the conditions for the development of information technologies industry in the Republic" dated June 30, 2017, Decree of the President of the Republic of Uzbekistan No. PD-3151 - "On measures to further expand the participation of industries and sectors of economy in improving the quality of training specialists with higher education" dated July 27, 2017, and other legal documents concerning this sphere, certain works have been intended, and this article also contributes to the fulfillment of the tasks mentioned above.

An effective factor in the success of educational reforms is the effective implementation of training activities for creative activities in the formation of competencies for training future teachers of fine arts on the basis of software tools.

Based on the ideas presented, future art teachers need to perform a number of tasks to increase the effectiveness of the education system using software tools. For example, it requires the selection of 
the field of education and the analysis of the necessary problems and the implementation of software tools.

\section{LITERATURE REVIEW}

While developing the system of continuous education, one of the innovative tasks nowadays is to provide more opportunities and qualitative educational services for students, and to train qualified personnel.

The Strategy of Actions for Uzbekistan's Development on Five Priority Areas in years 2017-2021 reflects the ways of further improving the system of continuous education through the development of the fields of science and education, enhancing the opportunities for qualittive educational services, as well as training the qualified personnel, improving the quality of general secondary education radically and developing the subjects of high demand.[1].

It emphasizes the importance of creating an e-learning environment, while ensuring the integration of science, education and industry, in radically improving the quality of education.

The Law of the Republic of Uzbekistan "On Education" and "The National Training Program" are the reflections of the great attention of our government to the education system, and serve as models for improving the educational process $[2,3]$.

Therefore, the professional training of future teachers of Fine Art is one of the important matters of ensuring a high level of preparation of the young generation for the implementation of the requirements of the National Training Program.

On March 7, 2002, the Ministry of Higher and Secondary Special Education, the Ministry of Public Education and the State Press Committee of the Republic of Uzbekistan signed a cooperative Decree under No. 71/22/44 "The concept of creating new generation of textbooks for the system of continuing education", which noted such tasks as: development of methodological, psychological, pedagogical, scientific and ideological requirements for creating programmed electronic educational -methodical complexes, giving a clear description of their existing forms and types for the correct and rational use of e-learning software systems, as well as identifying the strategic issues for the preparation of the national electronic educational and methodological literature[4].

Based on the important tasks described above, it is important to train future teachers of fine arts as teachers with high intellectual potential, professional maturity, capable of thinking and reasoning based on the achievements of modern science, as well as competitive, highly qualified personnel. [5]. In the work of V. Paronjanov "The XXI Century Textbook" the following considerations are given: "For the new generation of the present times, it is necessary to have modern knowledge and information. You will have to master a huge number of natural, technical, social and human sciences, which have no analogues in previous standards. Present teaching methods, technologies and textbooks do not meet these requirements"[6].

\section{METHODOLOGY}

On the basis of the method of analysis, the scientific and methodological literature related to the research topic has been systematically analyzed, advanced pedagogical experiments have been studied and generalized.

Based on the observation method, the system of conducting lessons and the organization of the 
"Composition" classes, that are taught in the Specialty 5110800 - "Fine Arts and Engineering Graphics" in higher educational institutions, have been observed.

The method of comparisons has been used to compare the educational literature on the subject "Composition", the methodological foundations of the formation of programmed electronic educational-methodological complexes, and didactic teaching opportunities.

On the basis of the experimental method, normative documents of higher education have been studied, experimental lessons have been organized and conducted on the subject "Composition" for the students of group 12-1 TS 20 (TS (abbr. form of "Tasviriysan'at") - Fine Art) in the specialty of 5110800 - "Fine Arts and Engineering Graphics", where virtual stands based on the programmed electronic educational- methodical complex and software means have been used.

\section{STATEMENT OF THE PROBLEM.}

At the present time, in the process of conducting practical lessons on the subject of "Composition", the following issues cause a negative impact on the acquisition of the subject: lack of proper material-technical base (lack of equipments for practical exercises); inapplicability and inconsistency of existing ones with innovative requirements, which are considered to be the elements of professional development of the teachers of higher educational institutions based on state standards and the fulfilment of qualification requirements.

In the process of training future teachers of the subject of Fine Art the concept "virtual", from a methodological point of view, renders a broad meaning, by the use of which high efficiency can be achieved in acquiring the subject "Composition" while conducting practical classes.

The main problem of using software in "Composition" classes today is the lack of sufficient development of methodological foundations. And those that have been worked out are not popularized and are not used in practical lessons in the process of education.

\section{RESULTS.}

It is possible to solve this problem by creating a virtual educational system, organically combining the tools designed to teach the subject "Composition", such as textbooks, tables, videos, programmed electronic educational-methodical complexes, slides and others.

The database of virtual information related to education consists of informational materials that make it possible to illustrate each registered topic [7].

The information of the multimedia catalog is related to certain topics based on the curriculum of the subject, the teacher can use the same multimedia object as a visual aid to explain various topics [8]. The use of visuals in practical classes of the subject of "Composition" serves to make the learning process more effective, because the content and basis of this subject consist of Composition, it is associated with a phased state of movement, the process of imaging and objects [9].

Below are some pictures from the practical classes conducted virtually (Figure 1). 


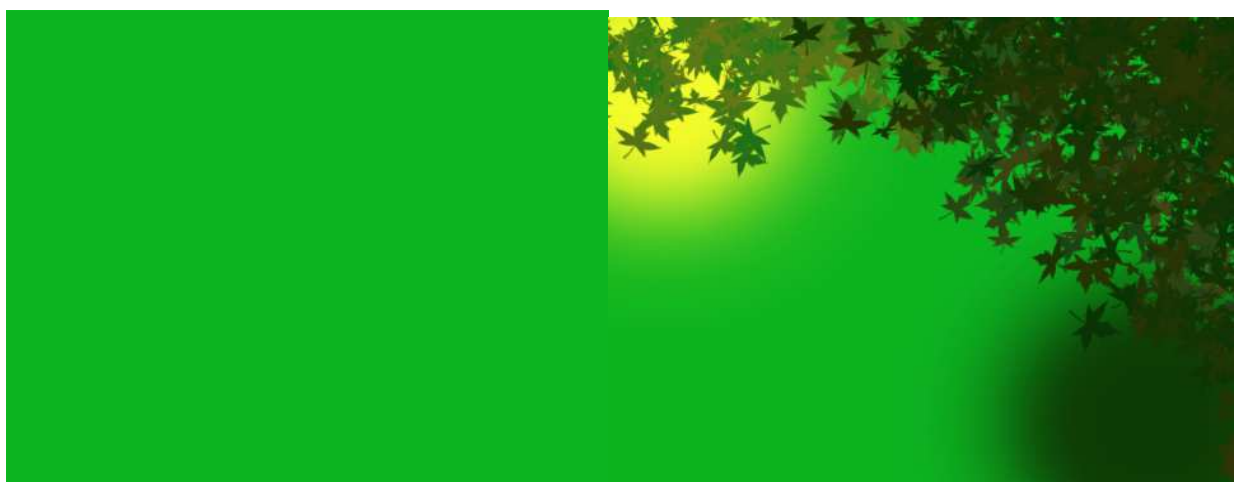

Figure 1. A virtual process of learning to create a scene in composition.

To observe the virtual process depicted in this figure of teaching the representation of the image of the scene in a "Composition" class, the left mouse button is clicked on the "Start" point. Painting the background of the format to depict the landscape composition on the theme of historical monuments of Bukhara.

The next process: click the left mouse button on the "Press" button once, and boundary lines of the proper placement in the format appear. In this process, you can see the placement of the still life picture in the format.

Also in the following process the left mouse button is once clicked on the "Start" button and at the bottom of the format are described lawns, historical monuments. (Figure 2).

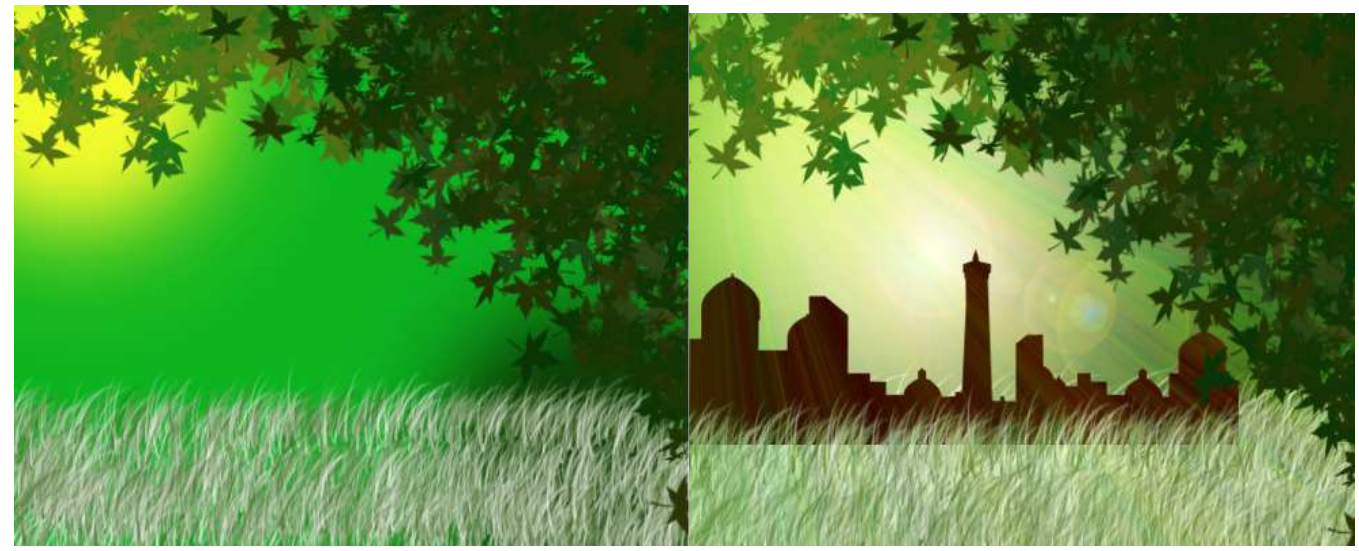

Figure 2. The process of depicting a landscape composition.

In the next process, those steps are repeated once again and a generalized composition of the landscape is drawn. (Figure 3).

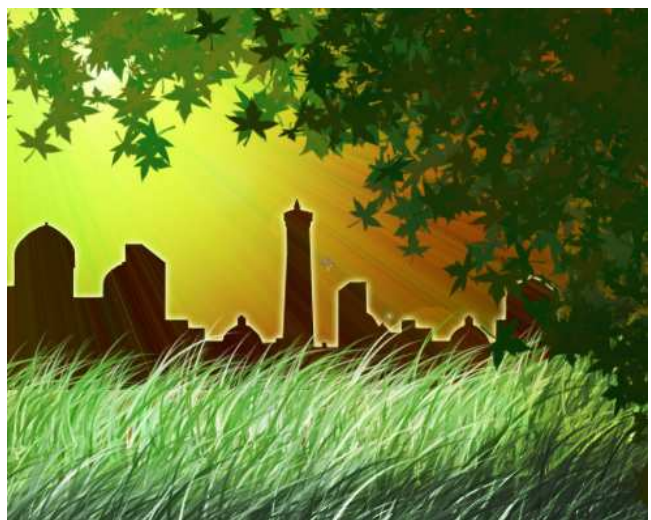

Figure 3. A generalized vivid image of the landscape composition. 
In virtual practical classes, future teachers of Fine Arts must perform several stages of depicting objects, proceeding not only from the structure, volume, spatial imagination, but also using special technological methods that make it possible to familiarize with the integrity of the object and see its small details. For example, it will be reasonable to use flash-animation program [10].

The content of this virtual practical lesson is intended to educate future teachers of Fine Arts.

Curriculum 5110800 - Fine Arts and Engineering Graphics (Future Teachers of Fine Arts) has been developed on the basis of the content of the curriculum of "Composition" course as a part of the professional block of subjects. The theoretical foundations of the effectiveness of using virtual practical training in the educational process are presented in it.

\section{CONCLUSIONS}

In conditions of insufficient virtual practical lessons conducted on the subject "Composition", it is possible to improve the methodology for the formation of knowledge, skills and qualifications of students.

The subject "Composition" on the basis of virtual education in higher education 5110800- Fine Arts and Engineering Graphics (Future Fine Arts Teachers) can be used to increase the effectiveness of students' learning.

The worked out content of virtual practical lessons of "Composition" consists of rather large database of video-animation and multimedia files. The teacher can use them to develop students' imaginations up to the required level and it is recommended that they be used to organize the lesson process effectively.

\section{REFERENCES}

1. Decree of the President of the Republic of Uzbekistan "ON THE STRATEGY OF ACTIONS FOR FURTHER DEVELOPMENT OF THE REPUBLIC OF UZBEKISTAN” - No. PD4947. www.lex.uz.

2. The concept of creating a new generation of textbooks for continuous education system - T .: Shark, $2002-$ p176.

3. K.T. Olimov "Theory and methods of creating textbooks." Academy of Sciences of the Republic of Uzbekistan. "Fan" Publishing House. - T .: 2010 y. - 158 b.

4. V. Paronjanov "The 21st century textbook: it can be 8,000 times more effective": (electronic document). Retrieved April 2, 2003.

5. Abduraxmonov. G. M. Textbook "Composition". Tashkent, 2007.-29 p.

6. In the process of development of creative abilities to teach future teachers of fine arts to describe nature and to form the features of emotional perception of forms Zbiórartykułównaukowych "Rozwójwspółczesnejnauki" "iSciencePolska", -Warszawa- 2018 y. page 28-34.

7. Methodics of using programmed means of education for the formation of professional skills of future teachers of fine art. European Journal of Research and Reflection in Educational Sciences, Progressive Academic Publishing. Amerika, 2020. -P. 94-99

8. Азимов С. С. Психологические аспекты формирования профессионального мастерства будущих учителей изобразительного искусства //Вестник науки и образования. - 2020. 

- №. 21-2 (99).

9. AS Samadvich, AS Nayimovich, SM Nosirovna .Technology of Teaching Fine Arts and Science Classroom .International Journal of Progressive Sciences and Technologies - 2021. 25 (2), 109-111

10. AS Samadvich, SM NosirovnaMethods of using Modern Pedagogical and Information Technologies of Fine Arts in the process of preparing Students. International Journal of Integrated Education-2021. - P. 101-104 